\title{
Pengembangan Kawasan Cagar Budaya Ampel sebagai Potensi Pariwisata Religi Di Surabaya
}

\author{
Dr Ir Rimadewi Suprihardjo ${ }^{1}$ \\ email : rimadewi54@yahoo.com
}

\begin{abstract}
Keberadaan Ampel semakin kuat dengan ditemukannya nilai ruang Kawasan Ampel. Kekuatan nilai religi membuat kawasan Ampel sebagai pusat syiar agama yang berpengaruh secara lokal, regional dan nasional bahkan internasional. Nilai histori akan berperan meningkatkan kawasan Ampel menjadi cagar budaya yang aktif (tidak pasif dan statis). Nilai sosial-budaya yang tumbuh di masyarakat Ampel dapat menjadi contoh masyarakat kota Surabaya lainnya dalam menggalang kekuatan kebersamaan, demikian pula nilai ruang ekonominya dapat meningkatkan peran perdagangan dengan skala lokal, regional dan nasional. Secara keseluruhan nilai ruang kawasan Ampel menjadi cermin pembangunan masyarakat seutuhnya. Keberadaan dan perkembangan Ampel tidak lepas dari pertumbuhan kota Surabaya dari sisi fisik dan ekonomi dari waktu ke waktu. Dari potensi nilai-nilai yang ada maka kekuatan kawasan tersebut sebagai pusat kegiatan pariwisata religi sangat kuat. Kekuatan tersebut dipertajam dengan adanya pengangkatan kearifan lokal dalam setiap kegiatan masyarakat yang berada dalam kawasan tersebut. Pertumbuhan jumlah wisatawan menjadikan indikator bahwa kawasan tersebut sangat berpotensi untuk dikembangkan sebagai kawasan pariwisata dalam skala nasional maupun Internasional. Penataan ruang dan managemen pariwisata menjadi poin penting yang perlu dilakukan dalam pengembangan kawasan Cagar Budaya Ampel sebagai kawasan pariwisata.
\end{abstract}

Key Word : faktor nilai ruang (space value factor), kawasan Cagar Budaya (Cultural Heritage Area), kegiatan pariwisata (tourism activity) 


\section{PENDAHULUAN}

$\begin{array}{rrr}\text { Konsep nilai ruang } & \text { kawasan } \\ \text { merupakan kunci } & \text { utama dalam }\end{array}$ pengembangan (pembangunan) sebuah kawasan karena dihasilkan dari kaitan erat antara kebutuhan dan pola hidup masyarakat secara fisik (materialistik) dan non fisik (keyakinan spiritual) (Supriharjo,2004)

Pengetahuan tentang konsep nilai ruang kawasan dapat menjelaskan bahwa dalam kehidupan masyarakat pada sebuah kawasan terdapat konsep-konsep pemanfaatan ruang dan nilai ruang. Konsep pemanfaatan ruang dapat dilihat dari beberapa faktor yaitu : (i) hubungan antar warga (etnis), (ii) kehidupan rutin sehari-hari, (iii) keyakinan spiritual yang dianut, (iv) sejarah pertumbuhan kawasan. Faktor-faktor tersebut mudah ditemukan dalam bentuk nyata dengan menggali atau eksplorasi terhadap fenomena empiri atau fakta aktual dalam bentuk fisik yaitu: (i) hubungan sosial dalam keruangan, (ii) ciri kegiatan dan kehidupan sehari-hari dalam keruangan. Bentuk fakta non fisik berupa : (i) keterikatan dan kebersamaan dalam perbedaan kultur, (ii) pikiran-pikiran atas keyakinan spiritual.

Hasil penelitian pada kawasan Ampel mengungkapkan bahwa nilai ruang dapat digali dari 4 (empat) faktor yaitu: (i) faktor sejarah pertumbuhan kawasan, (ii) faktor perilaku sosial budaya masyarakat, (iii) faktor lokasi dan lingkungan fisik, dan (iv) faktor suasana dan makna. Uraian tiap faktor akan dibahas dibawah ini dan merupakan proses membangun pengetahuan dan pengembangan kawasan.

Strategik issue yang berkembang masa kini adalahpengakuan yang berkembang bahwa warisan budaya dan konservasi merupakan tanggung jawab bersama dari pemerintahan, para pendukung, dan anggota komunitas. Namun secara bertahap mulai bergeser menjauh dari hanya membuat inventarisasi sumber daya warisan, menuju kepada pendekatan terpadu dan saling berkaitan antara sumbar daya dan potensi kedepan.

Warisan yang dahulu lebih dianggap sebagai catatan masa lalu saat ini harus menjadi bagian integral dari identitas perkotaan dan bermanfaat untuk masa depan. Sehingga Pelestarian warisan berharga dan kuno telah menjadi tantangan untuk pemerintah serta masyarakat sipil pada umumnya, bagaimana mengangkat eksistensinya disebabkan karena sudah banyak daerah bersejarah lama (cagar budaya) berada dalam bahaya kehancuran atas nama pembangunan ekonomi dan modernisasi.

\section{METODOLOGI}

Metode yang digunakan dalam penelitian ini adalah explorasi - kualitatif induksi (dalam payung paradigma fenomenologi), guna menggali dan merekam fenomena yang tumbuh di lokus terpilih. Hal tersebut didasarkan atas pertimbangan bahwa informasi yang digali merupakan nilai-nilai yang tidak terukur dengan angka, kejadian-kejadian yang direkam merupakan fenomena yang tumbuh didalam masyarakat.

Unit amatan berupa kawasan Ampel yang didalamnya terdapat individuindividu yang berada dalam kelompok masyarakat dari berbagai etnis yang berada didalam kesatuan kegiatan. Penentuan unit Informasi didasarkan atas sumber informasi berasal dari 3 unsur yaitu : (i) manusia, (ii) aktifitas, dan (iii) artefak. Keterkaitan dari ketiga unsur tersebut membentuk beberapa unit informasi yang digunakan sebagai dasar analisa. Unit informasi berbentuk suatu kegiatan yang dilakukan oleh manusia atau masyarakat dalam sebuah tempat atau ruang tertentu, yang mempunyai satu sifat yang sama.

Unit analisa yang digunakan dalam penelitian ini adalah "tema" yang terbangun dari gabungan dari berbagai unit informasi sebagai bahan dasar analisa. Unit analisis dibentuk dari integrasi aktifitas, pikiran dan ruang didalam masyarakat. Tema dibangun dari 
keterkaitan antara : (i) masyarakat terdiri dari penduduk dengan ragam etnis, (ii) kegiatan yang berupa aktifitas keseharian, pola hidup dan pikiran, (iii) lingkungan yang terdiri dari unsur tempat, ruang dan komponen fisik lain sebagai obyek, dan (iv) sejarah yang berupa perkembangan budaya, perubahan morfologi, dan pola spasial .

Analisa dilakukan dengan cara induktif karena konteks akan lebih mudah didiskripsikan, dan penafsiran idiografik. Melalui katagorisasi tema, induksi antar tema, dan kemudian dilakukan interpertasi serta penafsiran pada setiap tahap induksi untuk membangun makna dari aspek dan faktor yang berbeda. Pemaknaan dilakukan dengan kemampuan integratif dari manusia, indrawi, daya pikir dan akal budi (Muhajir,2000). Membangun konsep nilai ruang dengan mempertimbangkan beberapa ungkapan yang tersirat dan tersurat didalam pemaknaan. Kemudian akan dilanjutkan dengan membangun konsep pengembangan kawasan sebagai Kawasan Pariwisata.

Dengan adanya potensi nilai keruangan yang kuat dan potensi kegiatan masyarakat yang tetap eksis sampai saat ini, maka kawasan Cagar Budaya Ampel ini perlu dilestarikan dengan pendekatan pendekatan kawasan Pariwisata. Hal tersebut didasarkan atas kehidupan masyarakat adalah embrio kehidupan, dan pariwisata adalah esensi dari kehidupan tersebut.

\section{PEMBAHASAN}

Fokus pembahasan di arahkan kepada kekritisan warisan budaya untuk kota-kota berasal dari tiga faktor: (i)Faktor sosial : peningkatan citra dan identitas kota krn menyebabkan kebanggaan warga kota yang berintegrasi ke dalam keseharian hidup dan berperan dalam pengembangan sistem nilai masyarakat, (ii) Faktor Politik-ekonomi : melibatkan peran warisan/cagar budaya dalam pariwisata (sebagai peningkatan ekonomi lokal), dan mengangkat pentingnya arkeologi dan sejarah, (iii)Faktor Perencanaan : terutama berlaku untuk warisan budaya dan arsitektur dengan melibatkan penggunaan kembali, pembangunan kembali dan regenerasi objek warisan . Pelestarian dg mengintegrasikan cagar budaya ke dalam proses perkembangan yang lebih besar didalam kota secara keseluruhan. Pentingnya penempatan masalah pelestarian pusaka dalam keseluruhan proses pembangunan perkotaan, serta interlink dengan isu-isu lain seperti pengembangan pariwisata, revitalisasi ekonomi lokal dan pemerintahan daerah. Disisi lain adalah waspada dalam menanggapi tekanan dalam perkembangan masa depan yaitu dalam tekanan perkembangan ekonomi, dorongan modernisasi, sangat penting tidak hanya untuk melindungi sumber daya pariwisata, tetapi juga untuk mempromosikan pengembangan masyarakat yang berfokus pada lanskap budaya.

Esensi kegiatan pariwisata harus tumbuh dari kegiatan masyarakat yang eksis sepanjang masa. Nilai keruangan kawasan Ampel adalah bentuk eksistensi kegiatan masyarakat yang nyata. Hubungan antara kegiatan masyarakat dan pola keruangan sangat jelas. Dari temuan-temuan lapangan dan analisa maka akan disusun konsep pengembangan kawasan tersebut. Uraian analisis diawali dari eksplorasi faktorfaktor yag berperan di kawasan tersebut, dibawah ini:

\section{a. Faktor Sejarah Pertumbuhan Kawasan}

Perjalanan waktu menunjukan pertumbuhan suatu kawasan dari segi fisik maupun non fisik. Pola proses pertumbuhan kawasan Ampel bisa digunakan sebagai proses penggalian pola-pola dan ciri-ciri pertumbuhan sebuah kawasan. Ciri khusus pertumbuhan kawasan Ampel ditandai 
dengan adanya titik pusat yaitu masjid, makam dan permukiman. Hubungan antara masjid, makam dan permukiman sangat erat dan saling berkait dan mengikat.

Dalam periode waktu ke waktu yang terjadi di kawasan Ampel adalah "perubahan" dan "keajegan" berjalan bersama seperti yang terlihat pada perubahan morfologi kawasan Ampel. Setiap tahap perubahan fisik mempunyai pengaruh pada perilaku masyarakat. Perubahan fisik memerlukan waktu secara periodik, namun disisi lain didalam pertumbuhan terdapat adanya keajegan atau kemapanan yang berkaitan dengan eksistensi fisik dan non fisik yaitu adanya situs sebagai simbol dan prinsip hidup masyarakat.

Faktor sejarah berkaitan dengan waktu dan tahapan, setiap tahap mempunyai ciri yang terbangun dari hubungan kegiatan dengan wadahnya. Setiap ciri akan mempunyai tipe lingkungan yang mengungkapkan suasananya. Nilai kehidupan pada kawasan Ampel tumbuh pula secara bertahap yaitu dari awal kehidupan masyarakat agraris sebagai embrio, kehidupan dengan dasar religi membentuk kesamaan derajat manusia, nilai kehidupan dengan keberagaman etnis dan budaya, dan yang terakhir adalah kehidupan dengan kesamaan keyakinan, dalam keragaman yang diikat dalam satu kebersamaan.

Pola pertumbuhan kawasan Ampel berdasarkan tipe lingkungan yang terbangun serta cerminan pertumbuhan dasar kehidupan yang terjadi. Hal tersebut menunjukan bahwa faktor sejarah pertumbuhan sebuah kawasan dapat menggambarkan ciri dasar kehidupan masyarakat yang akan mempengaruhi nilai keruangan sebuah kawasan.

\section{b. Faktor Perilaku Sosial Budaya Masyarakat}

Perilaku sosial budaya masyarakat digali dari unsur etnis, agama, adat kebiasaan dan lokasi. Tiap etnis mempunyai karakter bawaan dan ciri khusus dalam perilaku, adat kebiasaan dan tatanan norma. Unsur agama juga membentuk perilaku, tatanan dan normanorma. Unsur lokasi mempengaruhi pula perilaku kegiatan se-hari-hari dan pembatasan secara fisik. Pada pembahasan yang terdahulu pola perilaku dan keyakinan etnis memberikan suatu konsep bahwa dengan adanya suatu ikatan keyakinan yang sama dapat mengendalikan perbedaan budaya perilaku dan sifat masing-masing etnis. Pola yang yang terbangun adalah: (i) kesamaan keyakinan spiritual, (ii) adaptasi sifat-sifat etnis, (iii) toleransi dalam sosial - budaya masyarakat, (iv) kesamaan dan keterikatan kebutuhan. Pola perilaku dan keyakinan tiap etnis menghasilkan satu pola dasar yang dapat digunakan untuk membangun konsepsi nilai ruang kawasan secara keseluruhan, yang intinya adalah kebersamaan dalam satu wadah kehidupan.

\section{c. Faktor Lokasi dan Lingkungan Fisik}

Lokasi permukiman menjadi faktor yang menentukan suasana dan arti suatu ruang. Setiap lokasi mempunyai kekhususan yang berbeda dengan lokasi lain. Ampel terletak pada lokasi yang merupakan "Kota Lama" di Kota Surabaya, dekat dengan pantai utara dan terdapat sungai besar (S. Pegirian) yang digunakan sebagai sarana transportasi dan perdagangan. Lingkungan fisik Ampel berkembang sesuai perjalanan sejarah dengan beberapa kelebihan dan keunikannya yang tidak pernah berubah secara internal maupun eksternal.

Tabel 1 Hubungan keunikan dengan ciri tampilan fisik Kawasan

\begin{tabular}{|c|c|l|}
\hline No & Keunikan & \multicolumn{1}{|c|}{ Ciri tampilan fisik } \\
\hline 1 & Histori & $\begin{array}{l}\text { Situs sebagai simbol } \\
\text { kuat kegiatan religi. } \\
\text { Interaksi yang erat antara } \\
\text { masjid-makam- } \\
\text { permukiman. }\end{array}$ \\
\hline 2 & Kultural & $\begin{array}{l}\text { Kekuatan religi dengan } \\
\text { adanya situs symbol dan } \\
\text { keragaman etnis dengan }\end{array}$ \\
\hline
\end{tabular}




\begin{tabular}{|c|c|l|}
\hline & & $\begin{array}{l}\text { pola pengelompokan } \\
\text { kegiatan }\end{array}$ \\
\hline 3 & Alam & $\begin{array}{l}\text { Lahan dengan air payau } \\
\text { yang mempunyai satu } \\
\text { sumber air tawar yang } \\
\text { tak pernah menurun } \\
\text { kuantitas dan kualitasnya }\end{array}$ \\
\hline 4 & Arsitektur & $\begin{array}{l}\text { Tampilan rumah } \\
\text { peninggalan maupun } \\
\text { rumah baru dengan } \\
\text { keragaman ciri etnis } \\
\text { yang pernah tinggal } \\
\text { disana }\end{array}$ \\
\hline 5 & Lokasi & $\begin{array}{l}\text { Pusat kota sebagai } \\
\text { kawasan "kota lama", } \\
\text { peninggalan kawasan } \\
\text { dan bangunan } \\
\text { bersejarah. Strategis dari } \\
\text { sisi ekonomi }\end{array}$ \\
\hline
\end{tabular}

Sumber : Hasil analisis Peneliti 2004

Lokasi dengan keunikan-keunikan tersebut membawa nilai kawasan menjadi berbeda dengan kawasan lain. Nilai kawasan tercermin dalam nilai-nilai keruangan yang berada didalamnya yang didasarkan atas sifat kegiatan yang diwadahinya.

\section{d. Faktor Suasana dan Makna}

Setiap kegiatan dan perilaku manusia selalu mempunyai makna baik yang terungkap maupun yang tidak terungkap ditinjau dari berbagai sikap dan sudut pandang tertentu. Makna digali dan diungkap berdasarkan fenomena empiri yang tampak maupun yang tersembunyi. Suasana dan makna digali dari ekspresi fisik kawasan, ciri kehidupan masyarakat dan ungkapan emosional masyarakat.

Suasana dan makna-makna yang terungkap lebih lanjut dipahami kedalaman ungkapannya melalui proses bukti logis (justifikasi) dan dicari keterkaitan antar makna berdasarkan hubungan ketergantungannya. Makna yang tertangkap mempunyai frekwensi dan intensitas yang berbeda sehingga hirarkhi makna dapat terbangun dari intensitasnya. Antar makna mempunyai ikatan ataupun keterkaitan untuk saling menjaga eksistensinya. Tiap makna tidak dapat berdiri sendiri karena makna muncul berdasarkan proses pertumbuhan, perubahan yang dilandasi filosofi hidup masyarakat. Makna keruangan memiliki sistim nilai yang kemudian merupakan nilai keruangan pada suatu kawasan. Nilai muncul dari suasana dan makna sehingga antara suasana dan makna dengan nilai dalam satu kawasan adalah satu kesatuan yang tidak terpisahkan.

Hubungan antara makna dan nilai sangat erat. Makna mempunyai tingkatan yang lebih tinggi dari pada nilai, pada dasarnya sesuatu tanpa makna tidak akan bernilai. Hubungan makna dan nilai-nilai dikawasan Ampel secara skematis dapat digambarkan bahwa didalam nilai tersirat makna yang berkaitan dengan keyakinan spiritual masyarakat, yaitu " kemudahan hidup dan kepuasan batin” (makna laten), dan tersurat yaitu makna yang berkaitan dengan kegiatan atau aktifitas yang dapat dinyatakan dalam bentuk kehidupan sehari-hari dan kegiatan perdagangan (makna manifest). Secara rinci substansi dirangkum dalam tabel 2 dibawah ini untuk melihat hubungan makna latent dengan makna manifest. Makna latent menunjukan bahwa tempat tersebut diakui penting bagi masyarakat Ampel yang memiliki keragaman latar belakang. Dirasakan sebagai ruang yang amat menyenangkan dan diperlukan untuk memenuhi kepuasan batin yang tidak dapat ditemui ditempat lain. 
Tabel 2 Nilai ruang dengan makna yang terkandung didalamnya.

\begin{tabular}{|c|c|c|}
\hline $\begin{array}{c}\text { Nilai } \\
\text { Ruang }\end{array}$ & Makna tersirat (laten) & Makna tersurat (manifest) \\
\hline Religi & $\begin{array}{l}\text { Ruang yang dapat } \\
\text { dirasakan sebagai tempat } \\
\text { mendapatkan kebahagiaan, } \\
\text { ketentraman, kemudahan } \\
\text { hidup dan barokah, karena } \\
\text { kedekatan dengan Wali } \\
\text { Sunan Ampel }\end{array}$ & $\begin{array}{l}\text { Ruang yang berfungsi dan dimanfaatkan sebagai } \\
\text { rutinitas kegiatan ibadah dan ziarah dengan } \\
\text { aktifitas sholat, tafakur, iktikaf, zikir,wirid, } \\
\text { tabaruk, tawassul. Kegiatan dakwah dengan cara } \\
\text { khotbah, pengajian, pendidikan agama. }\end{array}$ \\
\hline Histori & $\begin{array}{l}\text { Ruang dengan suasana } \\
\text { peninggalan masa lalu, } \\
\text { suasana dengan 35acral35a } \\
\text { sunan Ampel , suasana } \\
\text { 35acral dan keramat }\end{array}$ & $\begin{array}{l}\text { Ruang yang dapat menampilkan bangunan masjid } \\
\text { dengan ciri arsitektur bangunan Jawa yang } \\
\text { dibangun sekitar abad } 14 . \text { Benda-benda } \\
\text { peninggalan Sunan masih dapat dilihat seperti } \\
\text { migrab, bedug, menara dan pintu gerbang. } \\
\text { Kawasan makam yang dipenuhi oleh orang } \\
\text { berziarah di makam Sunan Ampel. }\end{array}$ \\
\hline $\begin{array}{l}\text { Sosial } \\
\text { budaya }\end{array}$ & $\begin{array}{lr}\text { Ruang yang } & \text { dapat } \\
\text { dirasakan } & \text { dalam } \\
\text { kebersamaan, } & \text { saling } \\
\text { menghargai, } & \text { saling } \\
\text { memiliki dan menjaga. }\end{array}$ & $\begin{array}{l}\text { Ruang yang digunakan bersama untuk berdagang, } \\
\text { bekerja, bermain, berkumpul, memasak, menjemur } \\
\text { pakaian, menyimpan barang, parkir kendaraan, dan } \\
\text { mempunyai hajatan . }\end{array}$ \\
\hline Ekonomi & $\begin{array}{l}\text { Ruang yang dapat } \\
\text { menampilkan } \\
\text { kesejahteraan, kepuasan } \\
\text { batin dan kesuksesan } \\
\text { usaha. }\end{array}$ & $\begin{array}{l}\text { Ruang dengan area yang digunakan untuk } \\
\text { perdagangan dan usaha yang semakin lama } \\
\text { meluas.Intensitas pengunjung semakin padat. } \\
\text { Jenis usaha yang sangat beragam. }\end{array}$ \\
\hline
\end{tabular}

Sumber : Hasil Analisis Peneliti (2004)

Tabel 3 Unsur dan faktor penentu sistim nilai

\begin{tabular}{|c|c|c|}
\hline \multirow[b]{2}{*}{ FAKTOR } & \multicolumn{2}{|r|}{ UNSUR } \\
\hline & Inti & Pola \\
\hline SEJARAH & $\begin{array}{l}\text { Lokus /Lokasi } \\
\text { Masyarakat }\end{array}$ & $\begin{array}{l}\text { Pola Pertumbuhan: } \\
\text { Situs / Simbol, Kegiatan Masyarakat } \\
\text { Pemanfaatan lahan }\end{array}$ \\
\hline $\begin{array}{l}\text { PERILAKU } \\
\text { SOSIAL-BUDAYA } \\
\text { MASYARAKAT }\end{array}$ & $\begin{array}{l}\text { Pola Perilaku } \\
\text { Keyakinan masyarakat }\end{array}$ & $\begin{array}{l}\text { Pola Ciri Nilai kehidupan : } \\
\text { Keragaman pola perilaku, etnis/budaya, } \\
\text { Kesamaan filosofis dasar (inti),Toleransi } \\
\text { antar etnis,Keterikatan kebutuhan }\end{array}$ \\
\hline $\begin{array}{l}\text { LOKASI DAN } \\
\text { LINGKUNGAN } \\
\text { FISIK }\end{array}$ & $\begin{array}{l}\text { Keunikan Lingkungan } \\
\text { (Lokasi) dalam bentuk } \\
\text { Natural (alam) dan } \\
\text { terbangun (binaan) }\end{array}$ & $\begin{array}{l}\text { Pola Ciri-ciri fisik. } \\
\quad \text { Geometrik, Keruangan, Simbol }\end{array}$ \\
\hline $\begin{array}{l}\text { NUANSA DAN } \\
\text { MAKNA } \\
\text { RUANG }\end{array}$ & $\begin{array}{l}\text { Makna, Intensitas, } \\
\text { Hirarkhi } \\
\text { Keterkaitan nilai }\end{array}$ & $\begin{array}{l}\text { Pola Keruangan : } \\
\text { Ungkapan makna dan nilai,Nilai ruang }\end{array}$ \\
\hline
\end{tabular}


Tabel 4. Faktor dan Unsur Dasar untuk Membangun Konsep Nilai Ruang

\begin{tabular}{|l|l|l|}
\hline \multicolumn{1}{|c|}{ UNSUR } & FAKTOR & \multicolumn{1}{c|}{ EMPIRI } \\
\hline $\begin{array}{l}\text { Masjid dan } \\
\text { makam }\end{array}$ & $\begin{array}{l}\text { Eksistensi } \\
\text { dan fungsi }\end{array}$ & $\begin{array}{l}\text { Tempat berkumpulnya orang yang beribadah (sholat, zikir, } \\
\text { wirid,dll). Banyaknya ulama dan ustad yang aktif dalam kegiatan } \\
\text { agama (dakwah dan pendidikan) }\end{array}$ \\
\hline Permukiman & $\begin{array}{l}\text { Situasi sosial } \\
\text { kawasan }\end{array}$ & $\begin{array}{l}\text { Suasana kehidupan sosial didalam permukiman tampil secara wajar } \\
\text { dalam bentuk hubungan sosial warga dalam gotong royong, saling } \\
\text { bergantung secara sosial dan ekonomi dalam satu ikatan } \\
\text { agama yang sama }\end{array}$ \\
\hline $\begin{array}{l}\text { Kehidupan } \\
\text { dan kegiatan } \\
\text { masyarakat }\end{array}$ & $\begin{array}{l}\text { Keragaman } \\
\text { kegiatan } \\
\text { yang saling } \\
\text { berkaitan }\end{array}$ & $\begin{array}{l}\text { Berbagai kegiatan yang bersifat religi, sosial, budaya, dan ekonomi } \\
\text { yang saling berkait. Kegiatan ibadah dan ziarah menghasilkan } \\
\text { kegiatan ekonomi. Hubungan dalam bidang usaha menimbulkan } \\
\text { rasa kebersamaan sosial dalam bentuk perkumpulan PKK, karang } \\
\text { taruna,arisan, dan lain sebagainya. } \\
\text { Kehidupan keluarga dan warga masyarakat lain bersatu dalam } \\
\text { kegiatan agama melalui kelompok2 pengajian }\end{array}$ \\
\hline Lokasi & $\begin{array}{l}\text { Historis- } \\
\text { strategis } \\
\text { secara sosial- } \\
\text { ekonomi }\end{array}$ & $\begin{array}{l}\text { Kegiatan ibadah dan ziarah memacu pertumbuhan ekonomi } \\
\text { kawasan.Kawasan Ampel lebih dikenal sebagai pusat perdagangan } \\
\text { benda-benda religi Islam, termasuk perlengkapan ibadah, baju } \\
\text { muslim, makanan khas Arab. }\end{array}$ \\
\hline
\end{tabular}

Sumber : Hasil Analisis Peneliti (2004)

Penetapan nilai ruang kawasan didasarkan atas: (i) penggalian faktorfaktor dasar, (ii) pola dan konsep lokal , (iii) sistim nilai, dan (iv) suasana dan makna keruangan. Didalam proses pembangunannya peran manusia atau masyarakat (community) menjadi unsur penting sebagai subyek pembahasan. Wadah atau fisik lingkungan binaan menjadi unsur pendukung, dan keduanya adalah sebagai masukan (input). Keunikan dan kelebihan lokasi digali dari perjalanan sejarah masyarakat serta kegiatannya dan dari perubahan fisik kawasan (morfologi). Dua unsur tersebut (keunikan dan kelebihan) memberikan kekhususan pada suatu kawasan. Kawasan Ampel mempunyai 5 (lima) unsur keunikan (histori, kultural, alam, arsitektur, dan lokasi),dimana setiap unsur memiliki tampilan fisik. Kelebihan kawasan Ampel dilihat dari aktifitas sehari-harinya, terutama kegiatan religi yang tidak bisa dicari ditempat lain. Kegiatan sosial- budaya dan kegiatan ekonomi yang berkaitan erat dengan kegiatan religi merupakan kelebihan lain yang tidak pula dapat ditemukan dikawasan lain. Kekhususan lokus menghasilkan makna yang spesifik sehingga pola keruangan serta nilai keruangan suatu kawasan tidak pernah sama.

Dengan demikian konsep nilai ruang dibangun berdasarkan beberapa faktor dan unsur- unsur penentu penting yang didapatkan pada tiap kawasan. Kawasan Ampel sebagai lokus kasus dapat menghasilkan suatu peran dalam pemanfaatan ruangnya. Salah satu fungsi ruang yang amat penting adalah fungsi pariwisata. Setiap keruangan yang terbangun dan perilaku masyarakat yang ada pada tiap-tiap keruangan menunjukkan budaya kearifan lokal yang sangat menarik, dan ekspresi atau manifestasi kegiatannya dapat dinikmati sebagai kegiatan wisata. Kekuatan kegiatan religi telah membangkitkan kegiatan wisata religi yang didasarkan atas nilai sejarah 
dan nilai religi yang terpancar pada kawasan tersebut. Perjalanan sejarah kegiatan religi menjadi dasar pengembangan kegiatan pariwisata. Fakta empiri yang terjadi sekarang adalah kegiatan Pariwisata religi yang sangat intens pada kawasan tersebut. Sebagai sebuah kawasan Cagar Budaya, kawasan Ampel harus dijaga eksistensi budayanya dan dijaga eksistensi fisik kawasannya.
Hal yang akan mengaburkan eksistensi adalah pencampur adukkan fungsi keruangan, membiarkan kegiatan-kegiatan soaial-budaya dan ekonomi berkembang tanpa panduan, dan kemudian dampaknya adalah kualitas kegiatan pariwisatanya akan ter degradasi karena kesemrawutan dan hilangnya estetika lingkungan.

Tabel 5. Citra Kawasan Ampel

\begin{tabular}{|c|c|c|c|}
\hline $\begin{array}{c}\text { Nilai } \\
\text { Kawasan }\end{array}$ & Orientasi & Posisi & Isi \\
\hline $\begin{array}{l}\text { Religius } \\
\text { and Social } \\
\text { Value }\end{array}$ & 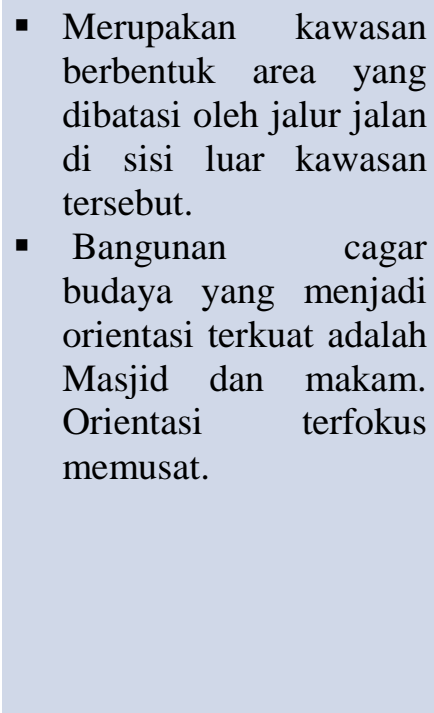 & $\begin{array}{l}\text { - Pemaknaan posisi } \\
\text { keruangan } \\
\text { berbentuk radial } \\
\text { dengan pusat } \\
\text { kegiatan ada pada } \\
\text { masjid dan makam. } \\
\text { - Bentuk radial } \\
\text { mengungkapkan } \\
\text { bahwa terdapat } \\
\text { lingkungan kawasan } \\
\text { dengan bentuk } \\
\text { cincin. Ran terluar adalah } \\
\text { - Ring anara } \\
\text { perbatasan antara } \\
\text { kegiatan usaha dan } \\
\text { kegiatan religi }\end{array}$ & $\begin{array}{l}\text { - Kegiatan religi mewarnai suasana } \\
\text { - Dawasan dengan sangat kuat. } \\
\text { - Dampak kegiatan religi } \\
\text { menghasilkan suasana kegiatan } \\
\text { wisata religi dengan segala warna } \\
\text { warni wisata. } \\
\text { - Kegiatan religi dengan nuansa Islam } \\
\text { (kegiatan ibadah) membawa kawasan } \\
\text { tersebut tidak pernah mati. } \\
\text { - Yang perlu dilakukan adalah } \\
\text { penataan zona kegiatan berdasarkan } \\
\text { tingkat privasi dan tingkat ekonomis. }\end{array}$ \\
\hline
\end{tabular}

\section{Simpulan}

Faktor dan unsur yang ditemukan pada kasus Ampel merupakan substansi penting dalam membangun nilai ruang kawasan. Yang dapat ditarik sebagai garis kesimpulan adalah, apabila kawasan yang mempunyai sejarah pertumbuhan yang didasarkan atas pengaruh religi, mempunyai masyarakat dengan kehidupan dan aktifitas yang bergantung dari satu sistim nilai kuat (religi dan histori), masih dapat bertahan dan mempunyai potensi berkembang, maka eksistensi kawasan Cagar Budaya kawasan Ampel harus tetap dijaga. Pelestarian kawasan Cagar Budaya di Ampel akan hidup dengan adanya kegiatan pariwisata. Karena kegiatan pariwisata akan menjadi potensi eksistensi nilai budaya, religi, sosial dan ekonomi untuk masyarakat Ampel.

\section{Rekomendasi}

Pelestarian kawasan Cagar Budaya di Ampel akan hidup dengan adanya kegiatan pariwisata,karena kegiatan pariwisata akan menjadi potensi eksistensi nilai budaya, religi, sosial dan ekonomi untuk masyarakat Ampel. Tahap pemikiran dan pelaksanaan: (i) Penetapan deliniasi kawasan Cagar Budaya Ampel,(ii) 
Pemasangan Signage dan peta informasi, dan (iii) Pengaturan zona-zona wisata didasarkan atas nilai-nilai dan fungsi ruang

\section{Daftar Pustaka}

Adisasmita,Rahardjo,1996. Teori-teori Lokasi dan Pengembangan Wilayah. Diktat Kuliah,Universitas Muslim Indonesia, Ujung Pandang. Alexander, Papaghorgiou,1971.Continuity and Change, Preservation in City Planning.Preager Publisher New York.

Chapin,F Stuart, Jr \& Edward, J Kaiser, 1979. Urban Land Use Planning. Third Edition. University of Illinois Press. Urbana. Chicago,London.

Gory. LA Mark and Pipkin .John, 1981. Urban Social Space. Wadsworth Publishing

Company, Belmont, California.

Kaiser,Edward,J\& David.R Godschalk \&

F.Stuart Chapin,Jr,1995.Urban
Land Use Planning. Fourth Edition. University of Illinois Press, Urbana, Chicago.

Kivell,Philip ,1993. Land and the City.

Pattern and processes of urban

Change. Routledge, London and New York.

Rapopport, Amos, 1977. Human Aspect of Urban Form. Pergamon Press New York.Rossi,

Aldo,1982. The Architecture of the City. The MIT Press.

Supriharjo, Rimadewi, (2003). Paper : Cultural Activity as Cultural Heritage in Ampel Area,Surabaya, Indonesia. International Symposium and Workshop, Managing Heritage Environment in Asia,Yogyakarta, Indonesia.

Supriharjo,Rimadewi,(2004). Nilai Ruang di Kawasan Ampel Surabaya. Disertasi (S3) Jur Arsitektur FT, Gadjah Mada, Yogyakarta 